Reviu Akuntansi dan Bisnis Indonesia, Vol. 2 No. 1, Hlm: 1-10, Juli 2018

Website: http://journal.umy.ac.id/index.php/rab

\title{
Kontribusi Kompetensi Sumber Daya Manusia, Standar Akuntansi Pemerintah, Dan Sistem Pengendalian Internal Pemerintah Terhadap Kualitas Laporan Keuangan Pemerintah : Studi Kasus Pada Satuan Kerja Perangkat Daerah Kab. Biak Numfor
}

\author{
Addinul Yaqin; Bambang Jatmiko \\ Program Studi Akuntansi Universitas Muhammadiyah Yogyakarta \\ I N F O A R T I K E L \\ Kata Kunci: \\ Kompetensi Sumber Daya \\ Manusia, Standar \\ Akuntansi Pemerintahan, \\ Sistem Pengendalian \\ Internal, dan Kualitas \\ Laporan Keuangan Satuan \\ Kerja Perangkat Daerah. \\ Jenis Artikel: \\ Penelitian Empiris \\ Correspondence: \\ bambang_jatmiko65@yahoo.com

\begin{abstract}
A B S T R A K
\end{abstract} \\ Penelitian ini bertujuan untuk menguji kontribusi kompetensi sumber \\ daya manusia, standar akuntansi pemerintahan, dan sistem pengendalian \\ internal terhadap kualitas laporan keuangan Pemerintah. Pengumpulan \\ data penelitian ini menggunakan survei kuesioner. Kuesioner disampaikan \\ kepada 100pegawai Satuan Kerja Perangkat Daerah (SKPD) Kabupaten \\ Biak Numforyang bekerja di bagianakuntansi/keuangan, sebanyak \\ 100kuesioner kembali diisi dengan lengkap dan dapat diolah. Penelitian \\ ini termasuk dalam penelitian kuantitatif. Sampel ditentukan dengan \\ teknik purposive sampling. Analisis data menggunakan regresi berganda \\ dengan menggunakan softwareSPSS 20.Hasil dari penelitian ini \\ menunjukkan bahwa kontribusi kompetensi sumber daya \\ manusiaberpengaruh positif terhadap kualitas laporan keuangan \\ pemerintah, standar akuntansi pemerintahberpengaruh positif terhadap \\ kualitas laporan keuangan pemerintah, dan sistem pengendalian \\ internalpemerintahberpengaruh positif terhadap kualitas laporan \\ keuangan pemerintah.
}

(C) 2019 RAB. Published by Universitas Muhammadiyah Yogyakarta

\section{PENDAHULUAN}

Organisasi sektor publik adalah organisasi yang bertujuan yang menyediakan atau memproduksi barang-barang publik. Dewasa ini akuntansi sektor publik telah mengalami perkembangan yang sangat pesat sehingga masyarakat menaruh perhatian yang lebih besar terhadap praktik akuntansi yang dilakukan oleh lembaga-lembaga pemerintah. Dalam tahap perkembangannya organisasi sektor publik kini diwarnai dengan munculnya fenomena menguatnya tuntunan akuntabilitas publik atas organisasi-organisasi sektor publik tersebut, baik pusat maupun daerah. Akuntabilitas dapat diartikan sebagai bentuk kewajiban mempertanggungjawabkan keberhasilan atau kegagalan pelaksanaan misi organisasi dalam mencapai tujuan dan sasaran yang telah ditetapkan sebelumnya, melalui suatu media pertanggungjawaban yang dilaksanakan secara periodik (Mardiasmo, 2006).

Sebagai salah satu bentuk pertanggungjawaban dalam penyelenggaraan pemerintahan yang diatur dalam Undang-Undang (UU) Nomor 17 Tahun 2003 tentang Keuangan Negara dan Undang-Undang (UU) Nomor 32 Tahun 2004 tentang Pemerintahan Daerah. Upaya konkrit untuk 
mewujudkan transparansi dan akuntabilitas pengelolaan keuangan pemerintah, baik pemerintah pusat maupun pemerintah daerah adalah dengan menyampaikan laporan pertanggungjawaban berupa laporan keuangan.

Laporan keuangan pemerintah yang dihasilkan harus memenuhi prinsip-prinsip tepat waktu dan disusun dengan mengikuti Standar Akuntansi Pemerintahan sesuai dengan Peraturan Pemerintah Nomor 24 Tahun 2005.Laporan keuangan pemerintah kemudian disampaikan kepada DPR/DPRD dan masyarakat umum setelah diaudit oleh Badan Pemeriksa Keuangan (BPK). Adapun komponen laporan keuangan yang disampaikan tersebut meliputi Laporan Realisasi Anggaran, Neraca, Laporan Arus Kas, dan Catatan atas Laporan Keuangan. Dalam Standar Akuntansi Pemerintahan (SAP). UU no 71 thn 2010 tentang Standar Akuntansi Pemerintahan dijelaskan bahwa laporan keuangan berkualitas itu memenuhi karakteristik, relevan, andal, dapat dibandingkan dan dapat dipahami.

Laporan keuangan merupakan sebuah produk yang dihasilkan oleh bidang atau disiplin ilmu akuntansi. Oleh karena itu, dibutuhkan Sumber Daya Manusia (SDM) yang berkompetensi untuk menghasilkan sebuah laporan keuangan pemerintah yang berkualitas. Begitu juga di entitas pemerintahan, untuk menghasilkan laporan keuangan yang berkualitas dibutuhkan Sumber Daya Manusia (SDM) yang memahami dan berkompetensi dalam akuntansi pemerintah.

Khususnya untuk Laporan Keuangan Pemerintah Daerah (LKPD), laporan keuangan tersebut nantinya harus disampaikan oleh Pemerintah Daerah sebagai bentuk pertanggungjawaban pelaksanaan Anggaran Pendapatan dan Belanja Daerah (APBD) kepada Dewan Perwakilan Rakyat Daerah (DPRD), Laporan Keuangan yang dimaksud setidak-tidaknya meliputi Laporan Realisasi Anggaran (LRA), Neraca, Laporan Arus Kas, dan Catatan atas Laporan Keuangan (CALK), sebagaimana tercantum dalam Undang-Undang No 17 Tahun 2003, Pasal 32. Undang-Undang No 17 Tahun 2003 juga mengisyaratkan bahwa laporan pertanggungjawaban pemerintah atau laporan keuangan pemerintah pada gilirannya harus diaudit oleh Badan Pemeriksa Keuangan (BPK) sebelum disampaikan kepada pihak legislatif sesuai dengan kewenangannya.

Pemeriksaan Badan Pemeriksa Keuangan (BPK) yang dimaksud adalah dalam rangka pemberian pendapat (Opini) sebagaimana yang diamanatkan oleh Undang-Undang No 5 Tahun 2004 tentang pemeriksaan pengelolaan dan tanggungjawab keuangan Negara. Permasalahan mengenai laporan keuangan yang masih minim dalam hal pertanggungjawabannya ini juga merupakan masalah klasik yang terus berulang setiap tahunnya. Badan Pemeriksa Keuangan (BPK) memberikan opini Wajar Tanpa Pengecualian (WTP) atas Laporan Keuangan Pemerintah Pusat (LKPP) Tahun 2016, sebelumnya BPK memberikan opini Wajar Dengan Pengecualian (WDP). Peningkatan opini dari WDP menjadi WTP karena pemerintah telah menindak lanjuti hasil pemeriksaan BPK atas LKPP Tahun 2015. Di samping opini dan permasalahan, BPK juga mengungkapkan hasil reviu atas pelaksanaan transparansi fiskal tahun 2016 yang menunjukkan bahwa pemerintah telah memenuhi sebagian besar kriteria pilar transparansi fiskal secara memadai. Reviu dilakukan berdasarkan Fiscal Transparency Code (FTC) Tahun 2014. (IHPS BPK Semester $12017)$.

Mulai terhitung dari tahun 2012 sampai dengan 2016. Opini yang disajikan oleh BPK RI atas Hasil Pemeriksaan LKPD seluruh tingkat pemerintahan dapat dilihat dalam tabel.

Tabel 1.1 Opini BPK RI atas Laporan Keuangan Pemerintah Daerah (LKPD) Tahun 2012-2016

\begin{tabular}{lllll}
\hline \multirow{2}{*}{ Tahun } & \multicolumn{4}{l}{ Opini LKPD Seluruh Tingkat Pemerintahan } \\
& TW & TMP & WDP & WTP \\
\hline 2012 & $1 \%$ & $15 \%$ & $61 \%$ & $23 \%$ \\
2013 & $2 \%$ & $9 \%$ & $59 \%$ & $30 \%$ \\
2014 & $1 \%$ & $6 \%$ & $46 \%$ & $47 \%$ \\
2015 & $1 \%$ & $5 \%$ & $36 \%$ & $58 \%$ \\
2016 & $0 \%$ & $4 \%$ & $26 \%$ & $70 \%$ \\
\hline
\end{tabular}

Sumber: www.bpk.go.id 
Dilihat dari tabel 1.1 diatas merupakan hasil dari audit Badan Pemeriksa Keuangan (BPK) RI terhadap laporan keuangan dari pemerintah pusat, kabupaten, maupun kota pada tahun 2012 sampai dengan 2016, menunjukkan bahwa terjadi perkembangan pemberian opini WTP terjadi peningkatan sebesar 47\%. LKPD yang mendapat opini WDP mengalami penurunan, pada tahun 2012 sebesar 35\%. Penurunan juga terjadi pada LKPD yang mendapat opini TMP sebesar 11\%, sedangkan yang mendapat opini TW dari BPK menjadi 0\%, sempat mengalami kenaikan menjadi 2\% pada tahun 2013. Berdasarkan data yang ada menunjukan bahwa semakin banyak laporan keuangan pemerintah daerah yang disusun telah memenuhi syarat atau kriteria yang sesuai dengan peraturan yang sedang berlaku.

Adapun hasil penelitian fenomena yang terjadi dari hasil audit BPK terhadap kualitas laporan keuangan daerah di tingkat pemerintah kabupaten dari tahun 2012 sampai dengan 2016.

Tabel 1.2 Opini Laporan Keuangan Pemerintah Daerah (LKPD) Tahun 2012-2016

\begin{tabular}{lllll}
\hline \multirow{2}{*}{ Tahun } & \multicolumn{4}{c}{ Opini LKPD Seluruh Tingkat Pemerintahan Kabupaten } \\
& TW & TMP & WDP & WTP \\
\hline 2012 & $2 \%$ & $17 \%$ & $63 \%$ & $18 \%$ \\
2013 & $3 \%$ & $10 \%$ & $61 \%$ & $26 \%$ \\
2014 & $1 \%$ & $8 \%$ & $50 \%$ & $41 \%$ \\
2015 & $1 \%$ & $7 \%$ & $38 \%$ & $54 \%$ \\
2016 & $0 \%$ & $5 \%$ & $29 \%$ & $66 \%$ \\
\hline
\end{tabular}

Sumber: www.bpk.go.id

Berdasarkan Tabel 1.2 diatas menunjukan bahwa terjadinya peningkatan kualitas LKPD pada setiap tingkat pemerintahan, seperti pada pemerintahan Kabupaten yang mengalami peningkatan cukup signifikan dimana LKPD yang mendapat opini WTP di tahun 2012 sebesar $18 \%$ menjadi $66 \%$ pada tahun 2016 ini berarti terjadi peningkatan sebesar $48 \%$.

Berdasarkan hasil pemeriksaan atas laporan keuangan oleh BPK RI sejak tahun 2012 sampai dengan tahun 2016, Kabupaten Biak Numfor memperoleh opini WDP, TW dan TMP selama periode lima tahun terakhir.

Tabel 1.3 Opini BPK RI atas Laporan Keuangan Pemerintah Daerah (LKPD) Kabupaten Biak Numfor Tahun 2012-2016

\begin{tabular}{lll}
\hline No & Laporan Keuangan Pemeritah Daerah & Opini BPK RI \\
\hline 1. & 2012 & Wajar Dengan Pengecualian (WDP) \\
2. & 2013 & Wajar Dengan Pengecualian (WDP) \\
3. & 2014 & Tidak Wajar (TW) \\
4. & 2015 & Tidak Menyatakan Pendapat (TMP) \\
5. & 2016 & Tidak Menyatakan Pendapat (TMP) \\
\hline
\end{tabular}

Sumber: www.bpk.go.id

Berdasarkan Tabel 1.3 diatas menunjukkan bahwa data mengenai opini yang diberikan auditor BPK terhadap Laporan Keuangan Pemerintah Daerah Kabupaten Biak Numfor. Data tersebut menyatakan bahwa Laporan Keuangan Pemerintah Daerah Kabupaten Biak Numfor memiliki opini WDP sejak tahun 2012 sampai 2013, tetapi pada tahun 2014 mendapat opini TW, dan selanjutnya pada tahun 2015 sampai 2016 Kabupaten Biak Numfor mendapat opini TMP yang menandakan bahwa dalam hal ini pemerintah makin menurun dalam hal pengelolaan laporan keuangan tidak megalami peningkatan selama lima tahun berturut-turut.

Penelitian ini merupakan replikasi dari penelitian terdahulu yang dilakukan oleh Wati, dkk (2014) dengan judul "Pengaruh Kompetensi Sumber Daya Manusia, Penerapan Standar Akuntansi Pemerintah dan Sistem Akuntansi Keuangan Daerah Terhadap Kualitas Laporan Keuangan Daerah" adapun perbedaan penelitian ini dengan penelitian sebelumnya adalah pada obyek yang diteliti, dimana penelitian sebelumnya menggunakan obyek SKPD Kabupaten Buleleng, sedangkan dalam penelitian ini menggunakan obyek SKPD Kabupaten Biak Numfor serta variabel 
independen penerapan Sistem Akuntansi Keuangan Daerah yang diganti menjadi Sistem Pengendalian Internal Pemerintah.

\section{TINJAUAN LITERATUR DAN PERUMUSAN HIPOTESIS}

\section{Stewardship Theory}

Teori stewardship adalah teori yang menggambarkan situasi dimana para manajer tidaklah termotivasi oleh tujuan-tujuan individu tetapi lebih ditujukan pada sasaran hasil utama mereka untuk kepentingan organisasi, sehingga teori ini mempunyai dasar psikologi dan sosiologi yang telah dirancang dimana para eksekutif sebagai steward termotivasi untuk bertindak sesuai keinginan prinsipal, selain itu perilaku steward tidak akan meninggalkan organisasinya sebab steward berusaha mencapai sasaran organisasinya. Teori ini didesain bagi para peneliti untuk menguji situasi dimana para eksekutif dalam perusahaan sebagai pelayan dapat termotivasi untuk bertindak dengan cara terbaik pada principahya (Donaldson dan Davis, 1991).

\section{Kualitas Laporan Keuangan}

Menurut PP No 24 Tahun 2005, Laporan Keuangan merupakan Laporan terstruktur mengenai laporan posisi keuangan dan transaksi-transaksi yang dapat dilakukan oleh suatu entitas pelaporan. Sedangkan menurut PP No 8 Tahun 2006, tentang Laporan Keuangan adalah bentuk pertanggung jawaban pengelolaan Keuangan Negara dan Daerah selama suatu periode.

\section{Kompetensi Sumber Daya Manusia}

Kompetensi adalah perpaduan pengetahuan, keterampilan dan sikap pribadi lainnya yang diperlukan untuk mencapai keberhasilan dalam sebuah pekerjaan, yang bisa diukur dengan menggunakan standar yang telah disepakati, dan yang dapat ditingkatkan melalui pelatihan dan pengembangan.Kompetensi meliputi aspek intent (niat), action (tindakan), dan outcome (hasil) (Marwansyah, 2012).

\section{Standar Akuntansi Pemerintah}

Berdasarkan Peraturan Pemerintah (PP) Nomor 24 Tahun 2005 tentang Standar Akuntansi Pemerintah (SAP) menerangkan bahwa anggaran merupakan pedoman tindakan yang akan dilaksanakan pemerintah meliputi rencana pendapatan, belanja, transfer, dan pembiayaan yang diukur dalam satuan rupiah, yang disusun menurut klasifikasi tertentu secara sistematis untuk suatu periode.

\section{Sistem Pengendalian Internal Pemerintah}

Pengendalian internal didefinisikan sebagai suatu proses yang dipengaruhi oleh sumber daya manusia dan sistem teknologi informasi yang dirancang untuk membantu organisasi mencapai suatu tujuan tertentu. Pengendalian internal merupakan suatu cara untuk mengarahkan, mengawasi, dan mengukur sumber daya suatu organisasi, serta berperan penting dalam pencegahan dan pendeteksian penggelapan (fraud).

\section{Kompetensi Sumber Daya Manusia Terhadap Kualitas Laporan Keuangan}

Transparansi dan akuntabilitas pengelolaan keuangan daerah, sebagai sebuah implementasi kebijakan publik dalam praktik, memerlukan kualitas sumber daya manusia yang memadai dari 
segi jumlah dan keahlian (kompetensi, pengalaman, serta informasi yang memadai), disamping pengembangan kapasitas organisasi (Insani, 2010).

Apabila Sumber Daya Manusia (SDM) dapat melaksanakan sistem akuntansi jika tidak memiliki kapasitas dan kompetensi yang disyaratkan, maka dapat menimbulkan kendala dalam melaksanakan fungsi akuntansi, maka kualitas sistem akuntansi menjadi buruk. Jika semakin baik kapasitas dan kompetensi Sumber Daya Manusia, maka semakin baik juga kualitas laporan keuangan pemerintah daerah.

Dengan demikian dapat disimpulkan bahwa kompetensi sumber daya manusia memberikan pengaruh positif terhadap kualitas laporan keuangan pemerintah.

\section{$H_{I} \quad$ : Kompetensi Sumber Daya Manusia Berpengaruh Positif Terhadap Kualitas Laporan Keuangan Pemerintah}

\section{Standar Akuntansi Pemerintah Terhadap Kualitas Laporan Keuangan}

Menurut Peraturan Pemerintah Nomor 24 Tahun 2005 tentang standar akuntansi pemerintah yang menjelaskan bahwa laporan keuangan yang berkualitas itu dapat memenuhi kualitas yang dapat dikehendaki yaitu, relevan, andal, dapat dibandingkan dan dapat dipahami. Pemerintah perlu untuk menerapkan standar akuntansi pemerintah untuk dapat meningkatkan kualitas laporan keuangan untuk tujuan umum dalam rangka meningkatkan keterbandingan laporan keuangan yang baik terhadap anggaran, antar periode, maupun antar entitas.

Dengan demikian dapat disimpulkan bahwa standar akuntansi pemerintah memberikan pengaruh positif terhadap kualitas laporan keuangan pemerintah.

\section{$\boldsymbol{H}_{2} \quad$ :Standar Akuntansi Pemerintah Berpengaruh Positif Terhadap Kualitas Laporan Keuangan Pemerintah}

\section{Sistem Pengendalian Internal Pemerintah Terhadap Kualitas Laporan Keuangan}

Pengendalian internal meliputi struktur organisasi, metode, dan ukuran-ukuran yang dikoordinasikan untuk menjaga kekayaan organisasi, mengecek ketelitian dan keandalan data akuntansi, mendorong efisiensi, dan dipatuhinya kebijakan pimpinan (Indriasari dan Nahartyo, 2008).

Masih banyak terjadi kebocoran maupun penyimpangan di dalam laporan keuangan yang menyebabkan laporan keuangan pemerintah daerah belum memenuhi karakteristik atau sebuah informasi yang disyaratkan. Maka dari itu pengendalian internal ditetapkan untuk menstandarisasi proses kerja, sehingga menjamin tercapainya tujuan organisasi dan mencegah terjadinya kesalahan didalam suatu entitas.

Dengan demikian dapat disimpulkan bahwa sistem pengendalian internal pemerintah memberikan pengaruh positif terhadap kualitas laporan keuangan pemerintah.

\section{$\mathrm{H}_{3} \quad$ : Sistem Pengendalian Internal Pemerintah Berpengaruh Positif Terhadap Kualitas Laporan Keuangan Pemerintah}

\section{METODE PENELITIAN}

Obyek penelitian ini adalah Satuan Kerja Perangkat Daerah (SKPD) Kabupaten Biak Numfor, sedangkan subjek dari penelitian ini adalah kepala dan staf bagian akuntansi dan keuangan di SKPD Kabupaten Biak Numfor. Dalam penelitian ini, jenis data yang akan digunakan adalah data primer yang diperoleh dari hasil kuesioner yang akan didistribusikan kepada kepala dan staf 
bagian akuntansi dan keuangan tersebut yakni kepala dan staf bagian akuntansi dan keuangan di satuan kerja perangkat daerah (SKPD) Kabupaten Biak Numfor.

Teknik yang digunakan dalam pengambilan sampel untuk penelitian ini yakni purposive sampling. Teknik pengumpulan data yang dilakukan dengan metode survei menggunakan kuesioner dengan menggunakan skala Likert. Dalam hal ini, peneliti melakukan pengujian dengan menggunakan teknik analisis regresi berganda dengan menggunakan software SPSS for Windows.

\section{HASIL DAN PEMBAHASAN}

\section{Analisis Regresi Berganda}

Tabel 4.10. Hasil Uji Regresi Linear Berganda

\begin{tabular}{ccccc}
\hline Variabel & B & t hitung & Sig t & Keterangan \\
\hline (Constant) & 3.962 & & & \\
Kompetensi Sumber Daya Manusia & 0.124 & 2.815 & 0.006 & Signifikan \\
Standar Akuntansi Pemerintah & 0.222 & 2.604 & 0.011 & Signifikan \\
Sistem Pengendalian Internal Pemerintah & 0.487 & 11.234 & 0.000 & Signifikan \\
F hitung & 115.316 & & & \\
Sig F & 0.000 & & & \\
Adjusted R Square & 0.776 & & & \\
\hline
\end{tabular}

Sumber : Data primer2018

\section{Uji Regresi Simultan (uji F)}

Berdasarkan Regresi Simultan, diperoleh nilai F-hitung sebesar 115,316dengan probabilitas $(\mathrm{p})=0,000$. Berdasarkan ketentuan uji $\mathbf{F}$ dimana nilaiprobabilitas $(\mathrm{p}) \leq 0,05$, Kompetensi Sumber Daya Manusia, Standar Akuntansi Pemerintah, dan Sistem Pengendalian Internal Pemerintahsecara simultan mampu memprediksi perubahan Kualitas Laporan Keuangan Pemerintah.

\section{Uji Regresi Parsial (uji t)}

\section{$\mathrm{Y}=3.962+0.124 \mathrm{X}_{1}+0.222 \mathrm{X}_{2}+0.487 \mathrm{X}_{3}+\mathrm{e}$}

\section{Kompetensi Sumber Daya Manusia}

Berdasarkan uji regresi parsial, diperoleh nilai t-hitung sebesar 2,815 koefisienregresi (beta) 0,124 dengan probabilitas $(\mathrm{p})=0,006$. Berdasarkan hasil olah datadimana nilai probabilitas $(\mathrm{p}) \leq$ 0,05 dapat disimpulkan bahwa Kompetensi Sumber Daya Manusia berpengaruh positif dan signifikan terhadap Kualitas Laporan Keuangan Pemerintah.

\section{Standar Akuntansi Pemerintah}

Berdasarkan uji regresi parsial, diperoleh nilai t-hitung sebesar 2.604 koefisien regresi (beta) 0,222 dengan probabilitas $(\mathrm{p})=0,011$. Berdasarkan hasil olah data dimana nilai probabilitas $(\mathrm{p}) \leq$ 0,05 dapat disimpulkan bahwa Standar Akuntansi Pemerintah berpengaruh positif dan signifikan terhadap Kualitas Laporan Keuangan Pemerintah.

\section{Sistem Pengendalian Internal Pemerintah}

Berdasarkan uji regresi parsial, diperoleh nilai t-hitung sebesar 11,234 koefisien regresi (beta) 0,487 dengan probabilitas $(\mathrm{p})=0,000$. Berdasarkan hasil olah data dimana nilai probabilitas $(\mathrm{p}) \leq$ 
0,05 dapat disimpulkan bahwa Sistem Pengendalian Internal Pemerintah berpengaruh positif dan signifikan terhadap Kualitas Laporan Keuangan Pemerintah.

\section{Koefisisen Determinasi $\left(\mathbf{R}^{2}\right)$}

Menunjukkan oleh nilai Adjusted R Square sebesar 0,776. Artinya, 77,6\% Kualitas Laporan Keuangan Pemerintah dipengaruhi oleh Kompetensi Sumber Daya Manusia, Standar Akuntansi Pemerintah, dan Sistem Pengendalian Internal Pemerintah.

\section{Pengaruh Kompetensi Sumber Daya Manusia Terhadap Kualitas Laporan Keuangan Pemerintah}

Hasil penelitian ini menunjukkan bahwa Kompetensi Sumber Daya Manusia berpengaruh positif terhadap Kualitas Laporan Keuangan Pemerintah. Hal tersebut terbukti dengan nilai t hitung sebesar 2,815 dengan probabilitas 0,006 dimana angka tersebut signifikan karena ( $\leq \leq 0,05)$. Artinya SDM yang ada di SKPD Kabupaten Biak Numfor memiliki tiga indikator yaitu pengetahuan, keterampilan atau keahlian dan sikap perilaku, Sehingga semakin baik kompetensi sumber daya manusia maka semakin baik kualitas laporan keuangan pemerintah,

\section{Pengaruh Standar Akuntansi Pemerintah Terhadap Kualitas Laporan Keuangan Pemerintah}

Hasil penelitian ini menunjukkan bahwa Standar Akuntansi Pemerintah berpengaruh positif terhadap Kualitas Laporan Keuangan Pemerintah. Hal tersebut terbukti dengan nilai t hitung sebesar 2.604 dengan probabilitas 0,011 dimana angka tersebut signifikan karena (p $\leq 0,05)$. Artinya SAP yang ada di SKPD Kabupaten Biak Numfor memiliki tiga indikator yaitu penerapan basis akrual, penerapan basis kas dan penyajian secara wajar, Sehingga semakin baik standar akuntansi pemerintah maka semakin baik kualitas laporan keuangan pemerintah,

\section{Pengaruh Sistem Pengendalian Internal Pemerintah Terhadap Kualitas Laporan Keuangan Pemerintah}

Hasil penelitian ini menunjukkan bahwa Sistem Pengendalian Internal Pemerintah berpengaruh positif terhadap Kualitas Laporan Keuangan Pemerintah. Hal tersebut terbukti dengan nilai t hitung sebesar 11,234 dengan probabilitas 0,000 dimana angka tersebut signifikan karena $(\mathrm{p} \leq 0,05)$.Artinya SDM yang ada di SKPD Kabupaten Biak Numfor memiliki lima indikator yaitu lingkungan pengendalian, penilaian resiko, kegiatan pengendalian, informasi dan komunikasi, dan pemantauan, Sehingga semakin baik sistem pengendalian internal pemerintah maka semakin baik kualitas laporan keuangan pemerintah.

\section{KETERBATASAN PENELITIAN}

Berdasarkan hasil penelitian yang telah dilakukan, terdapat beberapa keterbatasan dalam penelitian ini, diantaranya ruang lingkup penelitian hanya dilakukan di wilayah Kabupaten Biak Numfor sehingga penelitian ini terbatas generalisasinya. Penelitian ini menggunakan metode survei melalui kuesioner tanpa dilengkapi dengan metode observasi atau wawancara, sehingga kemungkinan besar informasi yang disampaikan responden rentan terhadap informasi bias. Penelitian ini hanya menggunakan variabel penerapan standar akuntansi pemerintahan, dan sistem pengendalian internal, sedangkan masih banyak variabel lain yang mempunyai pengaruh cukup kuat terhadap kualitas laporan keuangan satuan kerja perangkat daerah.

\section{KESIMPULAN}


Berdasarkan hasil analisis yang dilakukan maka dapat diketahui bahwa Kompetensi Sumber Daya Manusiaberpengaruh positif terhadap Kualitas Laporan Keuangan Pemerintah. Berdasarkan hasil analisis yang dilakukan dapat diketahui bahwa Standar Akuntansi Pemerintah berpengaruh positif terhadap Kualitas Laporan Keuangan Pemerintah. Berdasarkan hasil analisis yang dilakukan dapat diketahui bahwa Sistem Pengendalian Internal Pemerintah berpengaruh positif terhadap Kualitas Laporan Keuangan Pemerintah.

Saran Bagi Pemerintahan di Kabupaten Biak Numfor hasil dari penelitian ini diharapkan dapat meningkatkan kesadaran pemerintah daerah akan pentingnya Kompetensi Sumber Daya Manusia (SDM) dan memberikan masukan bagi pemerintah dalam menyusun laporan keuangan yang sesuai dengan Standar Akuntansi Pemerintahan (SAP), serta Sistem Pengendalian Internal (SPI) dalam meningkatkan kualitas laporan Keuangan. Bagi Masyarakat, penelitian ini diharapkan dapat menjadi bahan informasi untuk meningkatkan pemahaman masyarakat tentang pentingnya Kompetensi Sumber Daya Manusia (SDM), Penerapan Standar Akuntansi Pemerintahan (SAP), dan Sistem Pengendalian Internal (SPI) serta pengaruhnya terhadap Kualitas Laporan Keuangan Satuan Kerja Perangkat Daerah. Bagi Peneliti Selanjutnya, enelitian ini dapat digunakan sebagai bahan acuan bagi peneliti berikutnya yang berminat meneliti mengenai Kualitas Laporan Keuangan Pemerintah.

\section{DAFTAR PUSTAKA}

Peraturan Pemerintah Republik Indonesia No. 71 Tahun 2010. Tentang Standar Akuntansi Pemerintah.

Adhi, D. K., \& Suhardjo, Y. (2013). Pengaruh Penerapan Standar Akuntansi Pemerintahan dan Kualitas Aparatur Pemerintah Daerah terhadap kualitas laporan keuangan (studi kasus pada pemerintah kota Tual). Jurnal STIE Semarang, Vol. 5, No. 3.

Ahsani, I. (2016). Penerapan Standar Akuntansi Pemerintahan, Kompetensi Sumber Daya Manusia, Dan Sistem Pengendalian Internal Serta Pengaruhnya Terhadap Kualitas Laporan Keuangan Satuan Kerja Perangkat Daerah (Studi Pada Skpd Di Kabupaten Kotawaringin Barat, Kalimantan Tengah). Repository.umy.ac.id.

Angga Dwi Permadi. (2013). Pengaruh Sistem Akuntansi Keuangan Pemerintah Daerah terhadap Kualitas Laporan Keuangan Pemerintah Daerah Studi Kasus pada Dinas Bina Marga Kota Bandung.Skripsi Universitas Widyatama Bandung.

Anggraeni, D. T. (2015).Faktor-Faktor yang Mempengaruhi Keterandalan Pelaporan Keuangan Pemerintah Daerah (Studi pada SKPD di Kabupaten Sidoarjo).Jurnal Ilmu dan Riset Akuntansi, Vol. 3, No.3.

Anton, F. X. (2016). Menuju Teori Stewardship Manajemen. Majalah Ilmiah INFORMATIKA, Vol. 1, No. 2.

BPK RI, Ikhtisar Hasil Pemeriksaan Semester 1 Tahun 2016.www.bpk.go.id, Diakses Tanggal 23 Maret 2018, pukul 03.30 WIB.

Candrakusuma, D. A., \& Jatmiko, B. (2017). Dampak Komitmen Organisasi, Sistem Pengendalian Intern Pemerintah, Akuntabilitas Publik, Partisipasi Anggaran Dan Kejelasan Sasaran Anggaran Terhadap Kinerja Manajerial. Jurnal Bisnis dan Ekonomi, Vol. 24, No. 1.

Darise. (2007). Pengelolaan Keuangan Daerah. Cetakan II, Yogyakarta: PT INDEKS

Donaldson, L., \& Davis, J. H. (1991). Stewardship theory or agency theory: CEO governance and shareholder returns. Australian Journal of management, Vol. 16, No. 1.

Ghozali, I. (2011). Aplikasi Analisis Multivariate dengan Program SPSS, Edisi 5, Semarang: UNDIP.

Herawati, T. (2014). Pengaruh Sistem Pengendalian Intern Terhadap Kualitas Laporan Keuangan (Survei Pada Organisasi Perangkat Daerah Pemda Cianjur). STAR-Study \& Accounting Research, Vol. 11, No. 1. 
Ihsanti, E. (2014). Pengaruh Kompetensi Sumber Daya Manusia Dan Penerapan Sistem Akuntansi Keuangan Daerah Terhadap Kualitas Laporan Keuangan Daerah (Studi Empiris pada SKPD Kab. Lima Puluh Kota). Jurnal Akuntansi, Vol. 2, No. 3.

Indriasari, D., \& Nahartyo, E. (2008). Pengaruh kapasitas sumber daya manusia, pemanfaatan teknologi, dan pengendalian internal akuntansi terhadap nilai informasi pelaporan keuangan pemerintah daerah (studi pada Pemerintah Kota Palembang dan Kabupaten Ogan Ilir). In Symposium nasional akuntansi.

Insani, I. (2010). Standar Operasional Prosedur (SOP) Sebagai Pedoman Pelaksanaan Administrasi Perkantoran Dalam Rangka Peningkatan Pelayanan Dan Kinerja Organisasi Pemerintah. Penyempurnaan Makalah pada Workshop Manajemen Perkantoran di Lingkungan Kementerian Komunikasi dan Informatika. Bandung.

Jatmiko, B. (2011). Kontribusi Pengendalian Intern, Struktur Kepemilikan Institusi Dan Perubahan Ceo (Chief Execitive Officer) Terhadap Kinerja Perusahaan Dengan Melalui Penerangan Prinsip-Prinsip Good Corporate Governance (Survey Pada Perusahaan Go Public Yang Listing Pada Bursa Efek Jakarta). Repository.umy.ac.id.

Jatmiko, B. (2014). Kontribusi Dan Peran Pengelolaan Keuangan Desa Untuk Mewujudkananggaran Pendapatan Dan Belanja Desa Yang Transparan Dan Akuntabel (Survey Pada Perangkat Desa Di Kecamatan Ngaglik, Kabupaten Sleman, Yogyakarta). Repository.umy.acid.

Kiranayanti, I. A. E., \& Erawati, N. M. A. (2016). Pengaruh Sumber Daya Manusia, Sistem Pengendalian Intern, Pemahaman Basis Akrual Terhadap Kualitas Laporan Keuangan Daerah. E-Jurnal Akuntansi, Vol. 16, No, 2.

Kusumah, A. A. (2012). Pengaruh Penerapan Standar Akuntansi Pemerintahan Terhadap Kualitas Laporan Keuangan (Survei pada SKPD/OPD Pemerintahan Kota Tasikmalaya). Jurnal Akuntansi, Vol. 2.No.1.

Lasoma, V. A. (2012). Pengaruh Standar Akuntansi Pemerintah (SAP) terhadap Kualitas Laporan Keuangan Pemerintah Daerah pada Dinas Pendapatan Dan Pengelolaan Keuangan Dan Aset Daerah Kabupaten Gorontalo Utara. Jurnal Akuntansi Vol. 2.No.1.

Mardiasmo. (2006). Perwujudan Transparansi dan Akuntabilitas Publik Melalui Akuntansi Sektor Publik: Suatu Sarana Good Governance. Jurnal Akuntansi Pemerintah.Vol. 2, No. 1.

Marwansyah. (2012). Manajemen Sumber Daya Manusia, Edisi Kedua, Bandung: Alfabeta.

Moeheriono.(2014). Pengukuran Kinerja Berbasis Kompetensi. Edisi Revisi, Cetakan Kedua, Jakarta: Rajawali Pers.

Mulyadi.(2016). Sistem Akuntansi.Edisi Empat, Jakarta: Salemba Empat.

Ningtyas, P. E., \& Widyawati, D. (2016). Pengaruh Efektivitas Penerapan Standar Akuntansi Pemerintahan Terhadap Kualitas Laporan Keuangan Pemerintah Daerah. Jurnal Ilmu dan Riset Akuntansi, Vol. 4, No. 1.

Nordiwan, D. (2008). Akuntansi Pemerintahan. Jakarta: Salemba Empat.

Nugraheni, P., \& Subaweh, I. (2011). Pengaruh Penerapan Standar Akuntansi Pemerintahan Terhadap Kualitas Laporan Keuangan. Jurnal Ilmiah Ekonomi Bisnis, Vol. 13, No. 1.

Nurillah, A. S., \& Muid, D. (2014). Pengaruh kompetensi sumber daya manusia, penerapan sistem akuntansi keuangan daerah (sakd), pemanfaatan teknologi informasi, dan sistem pengendalian intern terhadap kualitas laporan keuangan pemerintah daerah (studi empiris pada skpd kota depok).(Doctoral dissertation, Fakultas Ekonomika dan Bisnis).

Putra, B. D., \& Amar, S. (2015). Pengaruh Kompetensi Sumber Daya Manusia, Penerapan Sistem Pengendalian Intern Pemerintah, dan Penerapan Standar Akuntansi Pemerintah Terhadap Kualitas Laporan Keuangan Pemerintah Kota Padang. Jurnal Riset Manajemen Bisnis dan Publik, Vol. 3, No. 1.

Rahmawati, A., Fajarwati, F. (2013) Statistik, Edisi I, Yogyakarta: Lab. Manajemen FE UMY Rivai, V. (2011). Manajemen Sumber Daya Manusia untuk Perusahaan.Jakarta: Rajawali pers.

Roviyantie, D. (2011). Pengaruh kompetensi sumber daya manusia dan penerapan sistem akuntansi keuangan daerah terhadap kualitas laporan keuangan daerah. Skripsi. Universitas Siliwangi. 
Roviyantie, D. (2013). Pengaruh Kompetensi Sumber Daya Manusia (SDM), Penerepan Sistem Akuntansi Keuangan Daerah Terhadap Kualitas Laporan Keuangan Daerah. Jurnal Ekonomi Akuntansi, Universitas Sliwangi Tasikmalaya.

Sekaran, B. \& Bougie, R. (2010). Recearch Methods for Bussines: A Skill-Building Approach. Sixth Edition,London: Jhon Wiley and Sons, inc

Sembiring, F. L. (2013). Pengaruh Kualitas Sumber Daya Manusia, Pemanfaatan Teknologi Informasi Dan Sistem Pengendalian Intern Terhadap Keandalan Dan Ketepatwaktuan Pelaporan Keuangan Pemerintah (Studi Empiris Pada Pemerintah Kota Padang). Jurnal Akuntansi, Vol.1, No. 1.

Septiana, L., Syofyan, E., \& Agustin, H. (2017). "Pengaruh Kompetensi Sumber Daya Manusia Dan Peran Audit Internal Terhadap Kualitas Laporan Keuangan Pemerintah Daerah (Studi Empiris pada Satuan Kerja Perangkat Daerah Kota Sawahlunto). Wahana Riset Akuntansi, Vol. 5, No. 1.

Sudiarianti, N. M., Ulupui, I. G. K. A., \& Budiasih, I. G. A. (2015). Pengaruh Kompetensi Sumber Daya Manusia Pada Penerapan Sistem Pengendalian Intern Pemerintah dan Standar Akuntansi Pemerintah Serta Implikasinya Pada Kualitas Laporan Keuangan Daerah.(Doctoral dissertation, Tesis, Universitas Udayana, Denpasar).

Syarifudin, A. (2014). Pengaruh Kompetensi SDM dan Peran Audit Intern terhadap Kualitas Laporan Keuangan Pemerintah Daerah dengan Variabel Intervening Sistem Pengendalian Internal Pemerintah (studi empiris pada Pemkab Kebumen).Fokus Bisnis: Media Pengkajian Manajemen dan Akuntansi, Vol. 13, No. 2.

Wati, K. D., Herawati, N. T., \& Sinarwati, N. K. (2014). Pengaruh Kompetensi SDM, Penerapan SAP, dan Sistem Akuntansi Keuangan Daerah terhadap Kualitas Laporan Keuangan Daerah. E-Journal S1 Ak Universitas Pendidikan Ganesha Vol 2 No. 1.

Windiastuti, R. (2014). Pengaruh Sumber Daya Manusia Bidang Akuntansi Dan Sistem Pengendalian Internal Terhadap Kualitas Laporan Keuangan Pemerintah Daerah (Studi Kasus Pada Dinas Pengelolaan Keuangan Dan Asset Daerah Kota Bandung)

Yudianta, E., Agus, G., \& Erawati, N. M. A. (2012). Pengaruh Sumber Daya Manusia Teknologi Informasi dan Pengendalian Intern terhadap Kualitas Laporan Keuangan. E-Jurnal Akuntansi Universitas Udayana. Vol. 1, No. 1.

Zeyn, E. (2011). Pengaruh good governance dan standar akuntansi pemerintahan terhadap akuntabilitas keuangan dengan komitmen organisasi sebagai pemoderasi. Jurnal Reviu Akuntansi dan Keuangan, Vol. 1, No. 1. 